\title{
Methods for the Assessment of Microbial Populations Recovered from Enclosed Aerosols
}

\author{
By R. E. STRANGE, J. E. BENBOUGH, P. HAMBLETON \\ AND K. L. MARTIN \\ Microbiological Research Establishment, Porton Down, Salisbury, Wiltshire
}

(Accepted for publication I6 March 1972)

SUMMARY

\begin{abstract}
The viability of microbial populations recovered from aerosols was determined by a slide culture technique and/or the radioactively labelled antibody method and the results were compared with those obtained by the more widely used Bacillus subtilis var. niger spore tracer technique. With Escherichia coli MRE I62, results with the three methods were in good agreement. Slide culture gave inaccurate results with Pasteurella tularensis, live vaccine strain (LVS) and $E$. coli MRE 160. Results with the spore tracer and radio-antibody methods in conjunction with determinations of viable numbers were in fair agreement when $P$. tularensis, $E$. coli MRE I60 and coliphage $\mathrm{T} 7$ were tested.
\end{abstract}

\section{INTRODUCTION}

Experimental aerobiology depends on accurate reliable methods for determining the viability of microbial populations recovered from enclosed aerosols. Estimates of the survival of microbes based solely on colony or plaque counts are inaccurate because physical losses due to deposition on surfaces or settling decrease the total count in an unpredictable manner. Determination of the total number of bacteria in aerosol samples by counts in counting chambers or the Coulter counter (Kubitschek, 1969), or measurement of scattered light (Ferry, Farr, Rose \& Blau, I95I ; Ferry, Brown \& Damon, I958 $a, b$ ) will not provide reliable results if the bacterial concentration is below a certain level or if microbial lysis occurs or interfering particulates are present. The usual method of compensating for physical losses in aerosols is to add a known concentration of a stable tracer compound or material to the microbial suspension before spraying; if the relationship between the concentrations of colony- or plaque-forming units and tracer in the unsprayed suspension is known, the proportion of the population that survives aerosolization can be determined from the ratio of plaque- or colony-forming units and tracer in samples of the aerosol.

Fluorescent compounds, radioisotopes and viable bacterial spores are commonly used as tracers (Anderson \& Cox, 1967) but all have certain disadvantages. Fluorescent compounds such as sodium fluorescein (Wolfe, 196I; Miller \& Artenstein, 1967) and Rhodamine B (Songer, 1967) or a radioisotope such as [ $\left.{ }^{32} \mathrm{P}\right]$ orthophosphate (Harper, I96I ; Harstad, 1965; Benbough, 1971) can be criticized on the following grounds. A substance of relatively small molecular weight will distribute evenly among the aerosol particles but, particularly with sparse microbial populations, all aerosol particles do not contain microbes; microbecontaining particles will have different physical properties from particles containing tracer alone and this may affect the ratio of tracer to microbial particles in samples collected from the cloud. Another and more serious criticism of sodium fluorescein is that it may be toxic to aerosolized bacteria and viruses, particularly in the presence of simulated solar radiation (Dorsey, Berendt \& Neff, 1970; Berendt \& Dorsey, 1971). 
According to Anderson \& Cox (1967), the preferred radiotracer technique involves the use of microbes with incorporated radioisotope such as ${ }^{35} \mathrm{~S}$ (Miller, Scherff, Piepoli \& Idoine, 196I), ${ }^{32} \mathrm{P}$ (Harper \& Morton, 1952) or ${ }^{14} \mathrm{C}$ (Anderson, 1966). Alternatively, a labelled suspension of killed tracer microbes is added to the test microbe suspension (Harper, Hood \& Morton, 1958; Miller et al. 196I ; Anderson, 1966). Radiotracer techniques cannot by applied to the assay of diluted microbial suspensions because the excessive amounts of radioactivity required would damage the organisms. Also the use of excessive quantities of radioactivity in the spray fluid is unduly hazardous and expensive.

Viable spores of Bacillus subtilis var. niger have been used extensively as a biological tracer (Harper \& Morton, 1952; Harper et al. 1958; Anderson, 1966; Cox, 1966; Benbough, 1969; Hambleton, 1970), but there is evidence that a proportion of the spores may die in the aerosol (Harper et al. 1958; Anderson, I966; Cox, 1966); we have confirmed this with the slide-culture method of Postgate, Crumpton \& Hunter (I96I) which showed that about $10 \%$ of initially viable spores lost viability (or became dormant) under certain conditions in an aerosol. Other experiments with suspensions of test bacteria with and without tracer spores showed that the apparent survival of the test bacteria may be affected by the presence of spores.

The direct determination of the viability of bacterial populations collected from aerosols with the slide culture technique of Postgate et al. (196I) eliminates problems associated with tracer methods. Cox \& Baldwin (1966) applied the technique to aerosolized bacteria collected directly on to a nutrient agar surface, and Mr G. J. Harper (personal communication) to samples of aerosols collected into membrane-filtered sampling fluids. However, the slideculture method cannot be applied to bacteria that form filaments (e.g. Bacillus species and Escherichia coli B) and results with populations of small bacteria with long generation times (e.g. Pasteurella tularensis, live vaccine strain) are unreliable.

The concentration of bacteria in aqueous suspensions can be accurately, specifically and rapidly determined with a radioactively labelled antibody technique (Strange, Powell \& Pearce, 197I) and the sensitivity of the method is sufficiently high to allow the assay of sparse populations of bacteria recovered from aerosols. Thus radio-assay in conjunction with determinations of viable number should provide a further means of estimating microbial survival.

In this paper we describe the evaluation of radioactively labelled antibody and slideculture techniques, in comparison with the Bacillus subtilis spore tracer method for the assessment of bacterial survival in aerosols. The feasibility of using a radio-antibody method to determine virus survival was also investigated.

\section{METHODS}

Micro-organisms. Escherichia coli strains MRE I60 and MRE I 62 were grown at $37^{\circ} \mathrm{C}$ in mannitol + salts medium (Strange, Dark \& Ness, 196I) or nutrient broth in shaken flasks ( $1 \cdot 5$ l) or a Porton-type stirred fermenter ( $500 \mathrm{ml}$ culture vessel; Herbert, Phipps \& Tempest, 1965), operated as a batch process. Cultures were seeded from overnight shaken flask cultures in the same medium. Bacteria were harvested and washed $(\times 2)$ with saline phosphate buffer (pH 6.5; Strange et al. 196I) by centrifugation and resuspended (equivalent to about $5 \mathrm{mg}$ bacterial dry $\mathrm{wt} / \mathrm{ml}$ ) in distilled water. The 'live vaccine strain' (Lvs) of Pasteurella tularensis (Tigertt, I962; Sharer, Klein \& Lincoln, 1968) was grown at $37^{\circ} \mathrm{C}$ for $\mathrm{I} 8 \mathrm{~h}$ in shaken flasks containing a medium similar to that described by Sharer et al. (1968); a heavy inoculum (equivalent to about $10 \%$ of the final population) of a fully grown culture in the same medium 
was used; the bacteria (about $2 \times 10^{10} / \mathrm{ml}$ culture) were not separated from the spent medium.

Suspensions of bacteriophage $\mathrm{T} 7$ were provided as crude lysates by the Microbial Products Section, Microbiological Research Establishment (MRE). Purified phage suspensions were prepared from crude lysate (Strange \& Martin, 1972).

Aerosol generation, storage and collection. Aerosols of bacteria or phage $\mathrm{T}_{7}$ with or without a tracer of washed heated $\left(60^{\circ} \mathrm{C}, \mathrm{I}\right.$ h) Bacillus subtilis var. niger spores were generated with a 3-jet Collison spray and stored in a 751 rotating drum (Goldberg, Watkins, Boerke \& Chatigny, 1958) at a controlled relative humidity. The spray suspension contained $3 \times 10^{9}$ to $10^{10}$ bacteria or about $10^{11}$ phage $\mathrm{T}_{7}$ plaque-forming units (p.f.u.)/ml and where appropriate, about $5 \times 10^{9}$ Bacillus subtilis var. niger spores $/ \mathrm{ml}$. Samples of aerosols were collected with Porton raised impingers (May \& Harper, 1957) containing $10 \mathrm{ml}$ of collecting fluid to yield suspensions of $10^{6}$ to $10^{7}$ bacteria or $10^{7}$ to $10^{9} \mathrm{p}$.f.u. $/ \mathrm{ml}$. The sterile collecting fluids used were saline phosphate buffer $(\mathrm{pH} 6.5$ to $7 \cdot \mathrm{I})$ for Escherichia coli, $1 \%(\mathrm{w} / \mathrm{v})$ peptone $+0.05 \%$ silicone $60+0.1 \%$ cysteine $\mathrm{HCl}+0.5 \%$ glucose for Pasteurella tularensis and nutrient broth for coliphage $\mathrm{T} 7$. When aerosol samples were to be assayed with a slide culture technique (Postgate et al. 196I), the collecting fluids were filtered through a Millipore membrane filter (GSWP; $0.22 \mu \mathrm{m}$ pore size).

Assay of colony- or plaque-forming units. Samples $(0.25 \mathrm{ml})$ of suitably diluted suspensions of Escherichia coli with or without Bacillus subtilis spores (as a tracer) were spread on to each of four tryptone glucose agar plates and colonies were counted after incubation for $20 \mathrm{~h}$ at $37^{\circ} \mathrm{C}$; when present, the characteristic orange-coloured colonies of $B$. subtilis var. niger were easily distinguished from the colonies of $E$. coli and differential counts were made. Samples of suspensions of Pasteurella tularensis containing $B$. subtilis spores were similarly spread on to both tryptone glucose agar plates and blood agar plates containing penicillin (Downs, Coriell, Chapman \& Klauber, 1947); the penicillin (Crystapen from Glaxo Laboratories Ltd, Greenford, Middlesex) concentration was Io units/ml (sufficient to inhibit the growth of $B$. subtilis). Colonies of $P$. tularensis were counted after incubation of the plates for 48 to $72 \mathrm{~h}$ at $37^{\circ} \mathrm{C}$. Coliphage $\mathrm{T} 7$ was assayed by counting plaques formed on lawns of $E$. coli as described by Benbough (1971).

Determination of the viability of bacterial suspensions by slide culture. The method described by Postgate et al. (196I) was used. An enriched medium (containing Difco yeast extract, Difco Casamino acids, nutrient broth, salts, glucose and set with agar) was used for the assay of Escherichia coli suspensions and slide cultures were incubated for 2.5 to $3.5 \mathrm{~h}$ at $37^{\circ} \mathrm{C}$. Microcolonies and undivided bacteria were counted under the microscope with dark ground illumination. Suspensions for assay containing $<5 \times 10^{7}$ bacteria/ml were concentrated by centrifugation at about $16000 \mathrm{~g}$ for $6 \mathrm{~min}$ in a Quickfit \& Quartz 'Microcentrifuge' (James A. Jobling and Co. Ltd, Stone, Staffordshire) and the bacteria resuspended in an appropriately small volume of saline phosphate buffer (pH 6.5). Several media were tested for rapid growth of Pasteurella tularensis on slide cultures; a medium that showed up the bacteria clearly under dark ground illumination and promoted the formation of distinguishable microcolonies within 12 to $18 \mathrm{~h}$ contained nutrient broth $(14 \%, \mathrm{v} / \mathrm{v})$, pepsin-hydrolysed sheep blood $(2.5 \%, v / v)$, glucose $(0.5 \%)$, cysteine hydrochloride $(0.1 \%)$ and histidine $(0.1 \%)$ set with agar $(\mathrm{I} \cdot 5 \%, \mathrm{w} / \mathrm{v})$. Constituents other than agar were mixed together (solutions of cysteine hydrochloride and histidine were first neutralized) and filtered twice through a Millipore membrane filter (GSWP, $0.22 \mu \mathrm{m}$ pore size); the filtered solution $(2.5 \mathrm{ml})$ was mixed with molten clarified agar solution $(7.5 \mathrm{ml})$ containing $90 \mathrm{mg} \mathrm{NaCl}$ and portions $(0.2 \mathrm{ml})$ of the mixture dispensed into metal holding rings (Postgate et al. I96I).

Determination of micro-organisms with ${ }^{125}$ I-labelled homologous antibodies. The assay 
procedures described by Strange et al. (1971) and Strange \& Martin (1972) were used. Suspensions of Pasteurella tularensis were killed by heating at $60^{\circ} \mathrm{C}$ for $\mathrm{I} \mathrm{h}$. Samples $(0 \cdot \mathrm{I}$ to $\mathrm{I} \mathrm{ml})$ of bacterial suspensions were incubated with ${ }^{125}$ I-labelled immunopurified homologous antibody reagents (50 to $200 \mu \mathrm{l} ; 0.5$ to $2 \mu \mathrm{g}$ antibody protein; 20 to $30 \mu \mathrm{Ci} / \mu \mathrm{g}$ ) for 6 to $30 \mathrm{~min}$ at $25^{\circ} \mathrm{C}$ and reaction mixtures filtered and washed on Millipore membrane filters $(0.45 \mu \mathrm{m} ; 2 \mathrm{~cm}$ diam. $)$ held in stainless steel filter jigs. Samples of phage suspension in nutrient broth or saline phosphate buffer $(\mathrm{pH} 7 \cdot 2)$ were diluted ( $\mathrm{I}$ in $\mathrm{IO})$ with distilled water and portions ( $\mathrm{I} \mathrm{ml}$ ) rapidly frozen and thawed six times; samples $(0.2$ to $0.4 \mathrm{ml}$ ) of disrupted phage suspensions were incubated with ${ }^{125}$ I-labelled immunopurified anti-phage globulin reagent $\left(50 \mu \mathrm{l} ; 0.5 \mu \mathrm{g}\right.$ antibody protein; $35 \mu \mathrm{Ci} / \mu \mathrm{g}$ ) for $\mathrm{I} 5 \mathrm{~min}$ at $25^{\circ} \mathrm{C}$, membrane-filtered anti-phage serum $(0 \cdot 1 \mathrm{ml})$ was then added and incubation continued for a further $6 \mathrm{~min}$. Phage reaction mixtures were filtered and washed on Millipore membrane filters $(0.22 \mu \mathrm{m} ; 2 \mathrm{~cm}$ diam.). Radioactivities of the membrane filter centres $(7 \mathrm{~mm}$ diam.) with retained labelled bacterial or phage immunocomplexes and 'assay blank' filters (labelled antibody solution alone) were measured with a sodium iodide crystal scintillation counter (Spectrometer NE 8622, Nuclear Enterprises, Reading, Berkshire). Counts were usually collected for I min and the mean count for the assay blank was subtracted from the mean count for the test sample to give the signal.

\section{RESULTS}

Calibration of the radioactively labelled antibody assays. Previous work showed that the relationship between the concentration of bacteria in a sample and the radioactive signal given by the separated ${ }^{125}$ [-labelled immune complex in the radio-assay was usually nearly linear (Strange et al. I97I); this also holds for coliphage T7 (Strange \& Martin, 1972). For the present work it was shown that a similar linear relationship existed between the concentration of the bacterial species or coliphage $T_{7}$ recovered in samples of aerosols and the radioactive signal produced in the radio-assay. Accurate reproducible results were obtained with minimum concentrations of $5 \times 10^{4}$ bacteria or $5 \times 10^{6}$ p.f.u. coliphage $/ \mathrm{ml}$ sample.

Determination of the viability of bacterial populations recovered from aerosols. Pasteurella tularensis. Attempts were made to determine directly the viability of populations of $P$. tularensis recovered from aerosols into membrane-filtered cysteine broth (see Methods) with a slide-culture method (Postgate et al. 1961). The peptic sheep blood agar medium (see Methods) promoted the growth of distinguishable micro-colonies within $\mathrm{I} 2$ to $\mathrm{I} 8 \mathrm{~h}$ at $37^{\circ} \mathrm{C}$ but detection of individual bacterial cells was difficult and, therefore, reliable results for the viability of populations could not be obtained.

Application of the radio-assay to determine the total number of bacteria in conjunction with colony counts of viable bacteria on blood agar plates containing penicillin allowed the viability of Pasteurella tularensis populations recovered from aerosols to be estimated (Table I); in general, the results agreed well with those from the Bacillus subtilis spore tracer technique (Table I). Data for the survival of $P$. tularensis aerosolized in the presence and absence of $B$. subtilis spores (Table I, comparison of A (ii) and B) suggest that the spores exerted a small but significant protective effect on the aerosolized vegetative bacteria.

Escherichia coli MRE 162. The viability of $E$. coli MRE 162 populations can be accurately determined with the slide culture method because this micro-organism rapidly forms discrete micro-colonies within 2 to $3 \mathrm{~h}$ at $37^{\circ} \mathrm{C}$ and individual cells are easily distinguished. The method gave good results with populations of $E$. coli MRE I62 recovered from aerosols 
Table I. The survival of Pasteurella tularensis (Lvs) recovered from aerosols stored at two relative humidities determined with Bacillus subtilis (var. niger) spores as tracer and/or by the radio-antibody method

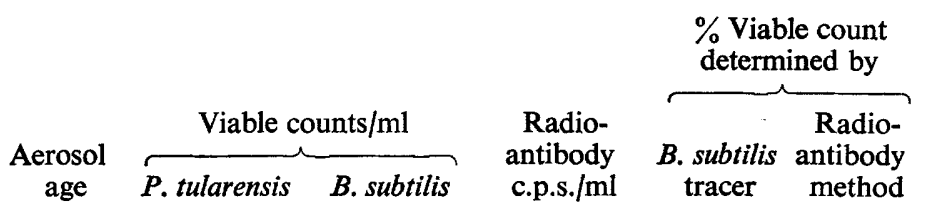

(A) Spray fluid contained $4 \cdot 78 \times 10^{9}$ P. tularensis $/ \mathrm{ml}$ (equivalent to $5.27 \times 10^{7}$ c.p.s. in the radio-antibody method) and $5.70 \times 10^{9}$ B. subtilis $/ \mathrm{ml}$

\begin{tabular}{|c|c|c|c|c|c|c|}
\hline & & (a) & (b) & (c) & $\begin{array}{c}\left(a / b / w^{*}\right. \\
\times 100)\end{array}$ & $\begin{array}{r}(a / c l y \dagger \\
\times 100)\end{array}$ \\
\hline (i) Relative humidity $=55 \%$ & $\begin{array}{l}\text { I s } \\
2 \mathrm{~min} \\
5 \mathrm{~min} \\
10 \mathrm{~min}\end{array}$ & $\begin{array}{c}\mathrm{I} \cdot 34 \times 10^{6} \\
8.88 \times 10^{3} \\
7 \cdot 20 \times 10^{2} \\
\text { none } \\
\text { detected }\end{array}$ & $\begin{array}{l}1.50 \times 10^{6} \\
1 \cdot 12 \times 10^{6} \\
9.00 \times 10^{5} \\
8.30 \times 10^{5}\end{array}$ & $\begin{array}{l}1.44 \times 10^{4} \\
7.23 \times 10^{3} \\
6.30 \times 10^{3} \\
4.73 \times 10^{3}\end{array}$ & $\begin{array}{l}106 \\
0.94 \\
0.09 \\
-\end{array}$ & $\begin{array}{c}102 \\
1 \cdot 30 \\
0 \cdot 12 \\
-\end{array}$ \\
\hline (ii) Relative humidity $=68 \%$ & $\begin{array}{l}\text { I s } \\
2 \mathrm{~min} \\
5 \mathrm{~min} \\
10 \mathrm{~min}\end{array}$ & $\begin{array}{l}1.48 \times 10^{6} \\
3.66 \times 10^{5} \\
2.66 \times 10^{5} \\
I \cdot 4 I \times 10^{5}\end{array}$ & $\begin{array}{l}I \cdot 62 \times 10^{6} \\
I \cdot 24 \times 10^{6} \\
I \cdot 51 \times 10^{6} \\
I \cdot 32 \times 10^{6}\end{array}$ & $\begin{array}{l}\mathrm{I} \cdot 72 \times 10^{4} \\
\mathrm{I} \cdot 07 \times 10^{4} \\
\mathrm{I} \cdot 3 \mathrm{I} \times 10^{4} \\
\mathrm{I} \cdot 09 \times 10^{4}\end{array}$ & $\begin{array}{l}\text { I08 } \\
34 \cdot 5 \\
21 \cdot 4 \\
13 \cdot 0\end{array}$ & $\begin{array}{l}94 \cdot 7 \\
37 \cdot 7 \\
22 \cdot 5 \\
14 \cdot 2\end{array}$ \\
\hline
\end{tabular}

(B) Spray fluid contained $5.52 \times 10^{9} P$. tularensis/ml (equivalent to $6.13 \times 10^{7}$ c.p.s. in the radio-antibody method)

(a)

$$
\begin{aligned}
\text { Relative humidity }=68 \% & \text { I s } \\
& 2 \mathrm{~min} \\
& 5 \mathrm{~min} \\
& \text { Io min }
\end{aligned}
$$

(b)

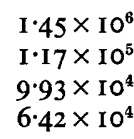

(c)

$\begin{array}{ccc} & & \times 100) \\ \mathrm{I} \cdot 52 \times 10^{4} & - & 104 \\ 6.70 \times 10^{3} & - & 19.3 \\ 7.97 \times 10^{3} & - & 13.7 \\ 7.20 \times 10^{3} & - & 9.8\end{array}$

$*_{W}=$ Ratio of $P$. tularensis/B. subtilis. $\quad \dagger y=$ Ratio of $P$. tularensis/radio-antibody c.p.s. in spray fluid (A).

$\ddagger z=$ Ratio of $P$. tularensis/radio-antibody c.p.s. in spray fluid (B).

Table 2. The survival of Escherichia coli (MRE strain 162) recovered from aerosols stored at $64 \%$ relative humidity determined with the radio-antibody and slide culture methods

The spray fluid contained $\mathrm{I} \cdot 9 \mathrm{I} \times 1 \mathrm{IO}^{10} \mathrm{E}$. coli $/ \mathrm{ml}$ (equivalent to $\mathrm{I} \cdot 28 \times 1 \mathrm{I}^{6}$ c.p.s. in the radio-antibody method).

Aerosol age
$\quad$ I s
$5 \mathrm{~min}$
10 $\mathrm{min}$
$30 \mathrm{~min}$

Viable count $/ \mathrm{ml}$

(a)

$$
\begin{aligned}
& 3.52 \times 10^{7} \\
& 2.27 \times 10^{7} \\
& I .65 \times 10^{7} \\
& I \cdot 13 \times 10^{7}
\end{aligned}
$$

$$
\begin{aligned}
& \text { Radio-antibody, } \\
& \text { c.p.s. } / \mathrm{ml}
\end{aligned}
$$$$
\text { (b) }
$$

$\%$ Viable count determined by

Radio-antibody

$\left(a / b / w^{*} \times\right.$ I0o) Slide culture

$\begin{array}{lll}3.36 \times 10^{3} & 71 & 69 \\ 2.52 \times 10^{3} & 60 & 67 \\ 2.48 \times 10^{3} & 45 & 52 \\ 1.84 \times 10^{3} & 48 & 44\end{array}$

${ }^{*} w=$ Ratio of $E$. coli/radio-antibody c.p.s. in spray fluid.

provided that the collecting fluid was filtered through a Millipore filter membrane $(0.22 \mu \mathrm{m}$ pore size) to remove extraneous particles capable of obscuring bacteria on an agar surface. The survival of $E$. coli MRE 162 in aerosols was therefore determined with the slide culture, spore tracer and radio-assay methods, respectively.

A comparison of the results obtained with the radio-assay (in conjunction with counts of viable bacteria) and the slide-culture method (Table 2) shows that, in general, there was 
Table 3. The survival of Escherichia coli (MRE strain 162) recovered from aerosols stored at $64 \%$ relative humidity determined with Bacillus subtilis (var. niger) spores as tracer and by the radio-antibody method

The spray fluid contained $1.00 \times 10^{10} \mathrm{E}$. coli/ml (equivalent to $5.54 \times 10^{5}$ c.p.s. in the radio-antibody method) and $7.94 \times 10^{10}$ Bacillus subtilis spores $/ \mathrm{ml}$.

\begin{tabular}{|c|c|c|c|c|c|}
\hline \multirow[b]{3}{*}{ Aerosol age } & \multirow{2}{*}{\multicolumn{2}{|c|}{ Viable counts $/ \mathrm{ml}$}} & \multicolumn{3}{|c|}{$\begin{array}{l}\% \text { Viable count } \\
\text { determined by }\end{array}$} \\
\hline & & & \multirow{2}{*}{$\begin{array}{l}\text { Radio-antibody } \\
\text { c.p.s./ml } \\
\text { (c) }\end{array}$} & \multirow{2}{*}{$\begin{array}{c}\text { B. subtilis } \\
\text { tracer } \\
\left(a \mid b / w^{*} \times 100\right)\end{array}$} & \multirow{2}{*}{$\begin{array}{c}\text { Radio- } \\
\text { antibody } \\
(a / c / y+\times 100)\end{array}$} \\
\hline & $\begin{array}{c}\text { E. coli } \mathrm{I} 62 \\
(a)\end{array}$ & $\begin{array}{l}\text { B. subtilis } \\
\text { (b) }\end{array}$ & & & \\
\hline I S & $1 \cdot 18 \times 10^{6}$ & $1 \cdot 30 \times 10^{6}$ & $82 \cdot 4$ & 72 & 79 \\
\hline $5 \mathrm{~min}$ & $5.64 \times 10^{5}$ & $7.23 \times 10^{5}$ & $52 \cdot 4$ & 62 & 60 \\
\hline $10 \mathrm{~min}$ & $6.02 \times 10^{5}$ & $1.00 \times 10^{6}$ & $79 \cdot 0$ & 48 & 43 \\
\hline $30 \mathrm{~min}$ & $3.87 \times 10^{5}$ & $7 \cdot 16 \times 10^{5}$ & $50 \cdot 1$ & 43 & 43 \\
\hline
\end{tabular}

Table 4. The survival of Escherichia coli (MRE strain 160 ) recovered from aerosols stored at $72 \%$ relative humidity determined with Bacillus subtilis (var. niger) spores as tracer and by the radio-antibody method

The spray fluid contained $2.66 \times 10^{9} \mathrm{E}$. coli $/ \mathrm{ml}$ (equivalent to $6.57 \times 10^{6}$ c.p.s. in the radio-antibody method) and $5 \cdot 10 \times 10^{\circ} B$. subtilis spores $/ \mathrm{ml}$.

\begin{tabular}{|c|c|c|c|c|c|}
\hline \multirow[b]{3}{*}{ Aerosol age } & \multicolumn{3}{|c|}{ 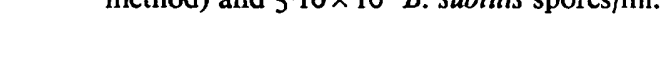 } & \multicolumn{2}{|c|}{$\begin{array}{l}\% \text { Viable count } \\
\text { determined by }\end{array}$} \\
\hline & \multicolumn{2}{|c|}{ Viable counts $/ \mathrm{ml}$} & \multirow[b]{2}{*}{$\begin{array}{l}\text { Radio-antibody, } \\
\text { c.p.s./ml } \\
(c)\end{array}$} & \multirow{2}{*}{$\begin{array}{c}\text { B. subtilis } \\
\text { tracer } \\
\left(a / b / w^{*} \times 100\right)\end{array}$} & \multirow{2}{*}{$\begin{array}{c}\text { Radio } \\
\text { antibody } \\
(a / c / y \dagger \times 100)\end{array}$} \\
\hline & $\begin{array}{c}E . \text { coli } 160 \\
(a)\end{array}$ & $\begin{array}{l}\text { B. subtilis } \\
\text { (b) }\end{array}$ & & & \\
\hline Is & $4.34 \times 10^{6}$ & $7.96 \times 10^{6}$ & $9.58 \times 10^{3}$ & 104 & IIO \\
\hline $2 \mathrm{~min}$ & $7.5 \times 10^{5}$ & $6.72 \times 10^{6}$ & $9.50 \times 10^{3}$ & $2 I \cdot I$ & $19 \cdot 2$ \\
\hline $40 \mathrm{~min}$ & $2.1 \times 10^{5}$ & $6.19 \times 10^{8}$ & $8.42 \times 10^{3}$ & $6 \cdot 5$ & $6 \cdot I$ \\
\hline $100 \mathrm{~min}$ & $6.3 \times 10^{4}$ & $4.25 \times 10^{6}$ & $9.68 \times 10^{3}$ & 2.9 & $I \cdot 7$ \\
\hline
\end{tabular}

good agreement. Also, results with the radio-assay agreed well with those by the spore tracer method (Table 3).

Escherichia coli MRE 160. Slide cultures of this micro-organism showed many filamentous forms and occasional bizarre shapes that were difficult to interpret (see Postgate et al. I96I). For this reason, particularly when the viability of stressed populations was determined, the results did not agree with those from total and viable bacteria counts. Therefore, only the radio-assay and spore tracer method were used to assess the survival of $E$. coli MRE I60 in aerosols.

Results obtained with the two methods were in good agreement (Table 4); the radio-assay could be used to determine Escherichia coli MRE 160 in the presence of Bacillus subtilis spores since ${ }^{125}$ I-labelled anti-E. coli globulin was not taken up by spores.

Coliphage $T_{7}$. Suspensions of coliphage in lysates of Escherichia coli MRE 160 with added Bacillus subtilis spores as a tracer were aerosolized and samples of the aerosol collected at intervals. The samples were assayed for viable spores by counts of colonies formed on tryptone agar, for replicating coliphage by plaque count on lawns of $E$. coli MRE I60 and for total phage particles by radio-assay. The survival characteristics of the coliphage based on 
Table 5. The survival of $T_{7}$ coliphage infectivity recovered from aerosols stored at $55 \%$ relative humidity determined with Bacillus subtilis (var. niger) spores as tracer and by the radio-antibody method

The spray fluid contained $\mathrm{I} \cdot 06 \times 10^{10}$ p.f.u. T7 coliphage $/ \mathrm{ml}$ (equivalent to $\mathrm{I} \cdot 267 \times 10^{5}$ c.p.s. in the radio-antibody method) and $2.60 \times 10^{9} \mathrm{~B}$. subtilis spores $/ \mathrm{ml}$.

\begin{tabular}{|c|c|c|c|c|c|}
\hline \multirow[b]{2}{*}{ Aerosol age } & \multirow[b]{2}{*}{$\begin{array}{l}\text { T7 coliphage } \\
\text { p.f.u. } / \mathrm{ml} \\
\text { (a) }\end{array}$} & \multirow[b]{2}{*}{$\begin{array}{l}\text { Viable count, } \\
\text { B. subtilis/ml } \\
\text { (b) }\end{array}$} & \multirow[b]{2}{*}{$\begin{array}{l}\text { Radio-antibody, } \\
\text { assay, } \\
\text { c.p.s./ml } \\
\text { (c) }\end{array}$} & \multicolumn{2}{|c|}{$\begin{array}{l}\% \text { Infectivity } \\
\text { determined by }\end{array}$} \\
\hline & & & & $\begin{array}{c}\text { B. subtilis } \\
\text { tracer } \\
\left(a \mid b / w^{*} \times 100\right)\end{array}$ & $\begin{array}{c}\text { Radio- } \\
\text { antibody } \\
(c / b / y \dagger \times 100)\end{array}$ \\
\hline I s & $8.67 \times 10^{6}$ & $9.46 \times 10^{6}$ & $5.17 \times 10^{2}$ & $22 \cdot 6$ & $20 \cdot I$ \\
\hline $5 \mathrm{~min}$ & $5.70 \times 10^{4}$ & $5.42 \times 10^{6}$ & $4.67 \times 10^{2}$ & 0.25 & 0.15 \\
\hline $10 \mathrm{~min}$ & $4.50 \times 10^{3}$ & $1.67 \times 10^{6}$ & $1 \cdot 27 \times 10^{2}$ & 0.066 & 0.043 \\
\hline $30 \mathrm{~min}$ & $2 \cdot 10 \times 10^{3}$ & $1.95 \times 10^{6}$ & $1 \cdot 35 \times 10^{2}$ & 0.027 & 0.019 \\
\hline
\end{tabular}

$* w=$ Ratio of $\mathrm{T}_{7}$ p.f.u./B. subtilis in the spray fluid. $\quad \dagger y=$ Ratio of $\mathrm{T}_{7}$ p.f.u./radio-antibody in the spray fluid.

data obtained with the spore tracer technique and radio-assay, respectively, were in fair agreement (Table 5). Results of experiments with suspensions of purified coliphage $\mathrm{T}_{7}$ showed similar agreement.

\section{DISCUSSION}

The slide-culture technique of Postgate et al. (I96I) is probably the simplest and most rapid of the methods for determining bacterial survival in aerosols. Its failure with populations of Pasteurella tularensis was, as anticipated, due to the small size and long generation time of this organism. While results for Escherichia coli MRE 162 were satisfactory, survival values of $E$. coli MRE I 60 were inaccurate because of the large proportion of filamentous and other forms present on slides.

Results for the survival of three test bacteria in aerosols at various relative humidities determined with the radio-antibody and spore tracer techniques, respectively, agreed reasonably well - suggesting that either method is sufficiently accurate for most experiments with bacteria. However, the radio-assay procedure has certain advantages. First, the total number of test bacteria recovered from an aerosol is determined directly, whereas in the spore tracer technique this value is determined indirectly from the viable spore count and will be inaccurate if spore viability is affected by aerosolization. Evidently, in the present work the spores used were relatively stable but this is not necessarily the case with all batches of spores. Second, the presence of spores may affect the apparent survival of the test bacteria. Thirdly, the method is more convenient to use with bacteria such as Pasteurella tularensis that grow more slowly than the spore tracer; in such cases the spore tracer method involves the plating of aerosol samples on to two media selective either for growth of spores or for the test bacteria.

The results obtained for the survival of coliphage $T 7$ in aerosols with the spore tracer and radio-antibody techniques, respectively, showed fair agreement but, as the death rate of the coliphage was extremely fast, the present data cannot be accepted as evidence that the spore tracer technique will give accurate results with other viruses. Particularly with virus aerosols generated from purified virus suspensions containing a spore tracer, the sizes and sampling characteristics of virus and spore particles are likely to differ markedly and thus lead to 
inaccurate results. This criticism does not apply to the radio-antibody technique since the latter allows aerosol survival studies to be made with pure virus suspensions.

A disadvantage of the radio-assay is the requirement for a radioactively labelled purified homologous antibody preparation for each micro-organism to be tested but immunopurification and radioactive iodination of antibody protein are easily performed (Strange et al. 197I). Antibody preparations labelled with ${ }^{125}$ I gradually lose both immuno- and radioactivity but may be used over a period of 3 to 4 weeks if stored at $4{ }^{\circ} \mathrm{C}$.

We thank our colleague Mr G. J. Harper for discussion and useful advice.

\section{REFERENCES}

ANDERSON, J. D. (1966). Biochemical studies of lethal processes in aerosols of Escherichia coli. Journal of General Microbiology 45, 303-313.

ANDERson, J. D. \& Cox, C. S. (1967). Microbial survival. Symposium of the Society for General Microbiology I7, 203-226.

Benbough, J. E. (1969). The effect of relative humidity on the survival of airborne Semliki Forest virus. Journal of General Virology 4, 473-477.

BENBOUGH, J.E. (1971). Some factors affecting the survival of airborne viruses. Journal of General Virology I0, 209-220.

BERENDT, R. F. \& DoRSEY, E. L. (1971). Effect of simulated solar radiation and sodium fluorescein on the recovery of Venezuetan Equine Encephalomyelitis virus from aerosols. Applied Microbiology 21, 447450.

Cox, C. S. (1966). The survival of Escherichia coli sprayed into air and into nitrogen from distilled water and from solutions of protecting agents as a function of relative humidity. Journal of General Microbiology 43, 383-399.

Cox, C. S. \& Baldwin, F. (1966). The use of phage to study causes of loss of viability of Escherichia coli aerosols. Journal of General Microbiology 44, I5-22.

Dorsey, E. L., BERENDT, R. F. \& NeFF, E. L. (1970). Effect of sodium fluorescein and plating medium on recovery of irradiated Escherichia coli and Serratia marcescens from aerosols. Applied Microbiology 20, 834-838.

Downs, C. M., Coriell, L. L., Chapman, S. S. \& Klauber, A. (1947). The cultivation of Bacterium tularense in embryonated eggs. Journal of Bacteriology 53, 89-100.

Ferry, R. M., Brown, W. F. \& Damon, E. B. (1958a). Studies on the loss of viability of stored bacterial aerosols. II. Death rate of several non-pathogenic organisms in relation to biological and structural characteristics. Journal of Hygiene 56, I 25-1 50.

Ferry, R. M., Brown, W. F. \& Damon, E. B. (1958b). Studies on the loss of viability of bacterial aerosols. III. Factors affecting death rates of certain non-pathogens. Journal of Hygiene 56, 389-403.

FerRY, R. M., FARR, L. E., Rose, J. \& BlaU, M. R. (1951). A study of freshly generated aerosols of Micrococcus candidus and Escherichia coli. Journal of Infectious Diseases 88, 256-27I.

Goldrerg, L. J., Watkins, H. M. S., Boerke, E. E. \& Chatigny, M. A. (1958). The use of a rotating drum for the study of aerosols over extended periods of time. American Journal of Hygiene 68, 85-93.

HAMBLEToN, P. (1970). The sensitivity of Gram-negative bacteria, recovered from aerosols, to lysozyme and other hydrolytic enzymes. Journal of General Microbiology 6r, 197-204.

HARPER, G. J. (1961). Airborne micro-organisms: survival tests with four viruses. Journal of Hygiene 59, 479-486.

HARPer, G. J., HoOd, A. M. \& Morton, J. D. (1958). Airborne micro-organisms: a technique for studying their survival. Journal of Hygiene 56, 364-370.

HARPER, G. J. \& MORTON, J. D. (1952). Bacillus subtilis spores labelled with radiophosphorus. Journal of General Microbiology 7, 98-106.

Harstad, J. B. (1965). Sampling submicron TI bacteriophage aerosols. Applied Microbiology 13, 899-908.

Herbert, D., Phipps, P. J. \& Tempest, D. W. (1965). The chemostat: design and instrumentation. Laboratory Practice 14, II 50-1 I6I.

Kurrtschex, H. E. (1969). Counting and sizing micro-organisms with the Coulter Counter. In Methods in Microbiology, vol. I, pp. 593-610. Edited by J. R. Morris \& D. W. Ribbons. London: Academic Press. 
MAY, K. R. \& HARPER, G. J. (1957). The efficiency of various liquid impinger samplers in bacterial aerosols. British Journal of Industrial Medicine 14, 287-297.

MilleR, W. S. \& ARTENSTEIN, M. S. (1967). Aerosol stability of three acute respiratory disease viruses. Proceedings of the Society for Experimental Biology and Medicine 125, 222-227.

Miller, W. S., SCHERfF, R. A., Piepoli, C. R. \& Idoine, L. S. (196I). Physical tracer for biological aerosols. Applied Microbiology 9, 248-25I.

Postgate, J. R., Crumpton, J. E. \& Hunter, J. R. (1961). The measurement of bacterial viabilities by slide culture. Journal of General Microbiology 24, 15-24.

ShaRer, J. M., KLEIN, F. \& LinCoLn, R. E. (1968). Growth and metabolism of live vaccine strain of Pasteurella tularensis. Applied Microbiology 16, 855-86r.

SONGER, J. R. (1967). Influence of relative humidity on the survival of some airborne viruses. Applied Microbiology $15,35-42$.

Strange, R. E., Dark, F. A. \& Ness, A. G. (196I). The survival of stationary phase Aerobacter aerogenes stored in aqueous suspension. Journal of General Microbiology 25, 61-76.

Strange, R. E. \& MarTIN, K. L. (1972). Rapid assays for the detection and determination of sparse populations of bacteria and bacteriophage $\mathrm{T} 7$ with radioactively labelled homologous antibodies. Journal of General Microbiology 72, I27-I4I.

Strange, R. E., Powell, E. O. \& Pearce, T. W. (197I). The rapid detection and determination of sparse bacterial populations with radioactively labelled homologous antibodies. Journal of General Microbio$\log y$ 67, 349-357.

TigERTT, W. D. (1962). Soviet viable Pasteurella tularensis vaccines. A review of selected articles."Bacteriological Reviews 26, 354-372.

WolfE, E. K. (196I). Quantitative characterisation of aerosols. Bacteriological Reviews 25, 194-202. 